\title{
Cyclosporin in the treatment of corticosteroid resistant autoimmune chronic active hepatitis
}

\author{
L D Jackson, E Song
}

\begin{abstract}
A 17 year old Asian patient with autoimmune chronic active hepatitis resistant to treatment with high dose corticosteroids and azathioprine was given cyclosporin at a dose of $5 \mathrm{mg} / \mathrm{kg} / \mathrm{day}$. Within two weeks of starting the cyclosporin treatment a favourable clinical and biochemical response was obtained and by one month serum aminotransferase activities were within normal limits. An attempted reduction in the daily dose of cyclosporin resulted in a relapse of the patient's disease. Remission was again attained by returning the dose of cyclosporin to $5 \mathrm{mg} / \mathrm{kg} / \mathrm{day}$. No significant side effects of the treatment have been shown. Cyclosporin seems to have a role in the treatment of corticosteroid resistant autoimmune chronic active hepatitis and its further evaluation is warranted. (Gut 1995; 36: 459-461)
\end{abstract}

Keywords: cyclosporin, hepatitis, corticosteroid resistance.

Autoimmune chronic active hepatitis (AICAH) is a disorder in which immune reactions against antigens are believed to be the pathogenic mechanism. ${ }^{1}$ It is now evident that recognition of self is essential to the normal functioning of the immune system ${ }^{2}$ and that AICAH points to a regulatory disorder within the immune system. ${ }^{3}$ The treatment of AICAH is immunosuppression and its goal is remission of disease as evidenced by a decline in the aminotransferase activities to less than twice the upper limit of the normal range as well as a reduction in the histological evidence of hepatic inflammation. Corticosteroids alone or in combination with azathioprine have been shown to improve liver function tests and enhance survival in most patients. ${ }^{4-6}$ About $70 \%$ of patients achieve remission. ${ }^{7-9}$ Cyclosporin has been used in the treatment of a number of autoimmune diseases. ${ }^{10-13}$ Its use in AICAH is limited to two cases in published works. ${ }^{1415}$ We describe our experience in the use of cyclosporin in a 17 year old man with AICAH resistant to high dose corticosteroids and azathioprine.

\section{Case report}

The patient, a 17 year old Asian Indian man, was well until September 1991 when he presented with a two week history of jaundice, malaise, weight loss, and vague right hypochondrial pain. Examination showed deep jaundice and hepatosplenomegaly. There had been no exposure to drugs, blood transfusions or alcohol. There was no family history of hepatic illnesses. Laboratory studies gave these results: aspartate aminotransferase (AST) 1031 $\mathrm{U} / \mathrm{l}$, alanine aminotransferase (ALT) $820 \mathrm{U} / \mathrm{l}$, total bilirubin $400 \mu \mathrm{g} /$, antinuclear factor positive (titre 1/640), antismooth muscle antibody positive (titre 1/320). Hepatitis A, B, and C serological tests were negative. Protein electrophoresis showed a total protein of $102 \mathrm{~g} / \mathrm{l}$ with a normal albumin concentration of $34 \mathrm{~g} / 1$ and hypergammaglobulinaemia of $52 \mathrm{~g} / 1$ (normal =9-18 g/l). An open wedge liver biopsy was performed under cover of fresh frozen plasma because of a prolonged bleeding time $(\mathrm{INR}=2)$. Histological examination showed bridging necrosis accompanied by a severe chronic inflammatory infiltrate of lymphocytes and plasma cells extending from the portal tracts into the lobules in keeping with the diagnosis of autoimmune chronic active hepatitis. There was no evidence of cirrhosis. Treatment was started with a daily oral dose of $30 \mathrm{mg}$ prednisone.

During the ensuing two months the patient's aminotransferase activities decreased $\mathrm{AST}=221 \mathrm{U} / 1$ and $\mathrm{ALT}=188 \mathrm{U} / \mathrm{l}$ ) but he became profoundly cushingoid and developed a gastric ulcer, which was treated successfully with ranitidine $300 \mathrm{mg}$ twice daily. An attempt was then made to reduce the patient's corticosteroid dose (October 1991), but his liver disease relapsed with a significant rise in his transminsase activities (AST $=1400 \mathrm{U} / 1$ and $\mathrm{ALT}=1098 \mathrm{U} / \mathrm{l}$ ) that required a hospital admission. Azathioprine at a dose of $1 \mathrm{mg} / \mathrm{kg}$ was introduced in combination with the prednisone but resulted in an attack of pancreatitis and had to be stopped.

Over the next six months the patient was maintained with prednisone $30 \mathrm{mg}$ daily. Remission was never achieved with aminotransferase activities remaining in the 100-150 $\mathrm{U} / \mathrm{l}$ range. The patient remained cushingoid and suffered a recurrence of his gastric ulcer. An attempt was made to reintroduce the azathioprine but the patient developed severe acute pancreatitis, which was accompanied by 
Prednisone

Cyclosporin A
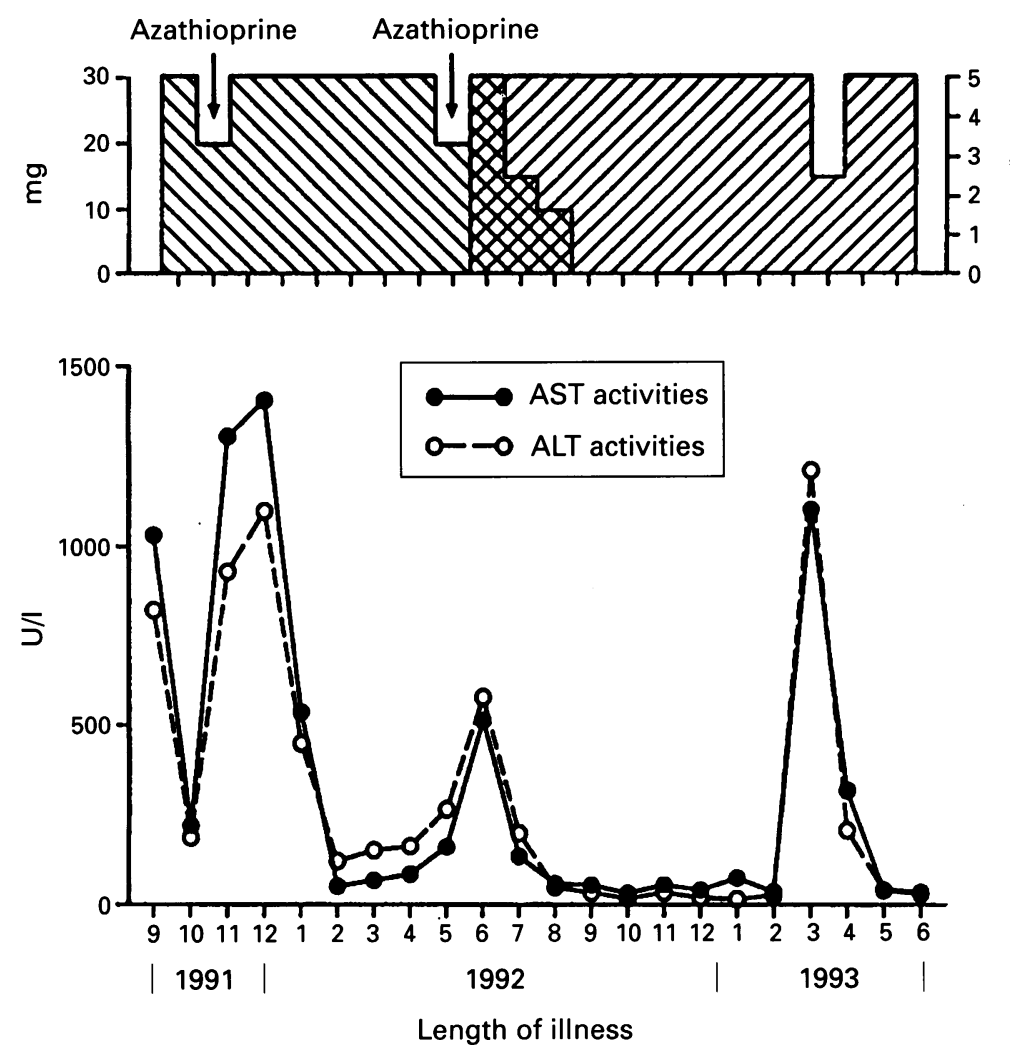

Aminotransferase activities as a result of treatment.

a considerable rise in transminase activities (June 1992). At this stage (July 1992) a therapeutic trial of cyclosporin was begun after informed consent was obtained from the patient's parents.

The patient was admitted to hospital and cyclosporin was begun at $5 \mathrm{mg} / \mathrm{kg} /$ day orally in two divided doses. The patient was carefully monitored for the development of hypertension, electrolyte abnormalities, fall in white cell count, and decrease in creatinine clearance. Cyclosporin trough concentrations were maintained at $50-300 \mathrm{ng} / \mathrm{ml}$. The cyclosporin assay used is the TDX system (Abbott Labs, Illinois, USA) in which cyclosporin and its metabolites (AM1, AM19, AM9, AM4N, and AM1C) are measured using fluorescence polarisation immunoassay technology. Within two weeks there was a favourable symptomatic and biochemical response with aminotransferase activities falling to normal (within one month) for the first time since the onset of the illness. The patient was weaned from prednisone and the noticeable cushingoid features resolved.

The patient remained in remission until March 1993 when an attempt was made to halve the dose of cyclosporin given. Within a period of two weeks the aminotransferase activities had risen dramatically (AST $=1103$ $\mathrm{IU} / \mathrm{ml}$ and $\mathrm{ALT}=1212 \mathrm{IU} / \mathrm{ml}$ ). Cyclosporin was once again introduced at a dose of 5 $\mathrm{mg} / \mathrm{kg} /$ day. Again the response was dramatic with aminotransferase activities returning to normal values $(\mathrm{AST}=41 \mathrm{IU} / \mathrm{ml}, \mathrm{ALT}=40$
$\mathrm{IU} / \mathrm{ml}$ ) within six weeks of increasing the dose of cyclosporin. Currently the patient is in remission receiving cyclosporin alone.

\section{Discussion}

The treatment of AICAH is immunosuppression and the drugs used to achieve remission in most cases are corticosteroids alone or in combination with azathioprine. Side effects of the corticosteroids are dose dependent and include changes such as cushingoid appearance, weight gain, acne, osteoporosis, myopathy, cataract formation, irritability, and psychosis. ${ }^{16-18}$ Severe corticosteroid side effects such as gastric ulceration, diabetes, and compression fractures occur in $16 \%$ of patients with AICAH. ${ }^{19}$ Azathioprine is an analogue of 6 mercaptopurine and it is this last metabolite that is responsible for most of the side effects. ${ }^{20}$ Mercaptopurine interferes with the synthesis of adenine and guanine nucleotides but its exact mechanism of action in AICAH is unknown. ${ }^{20}$ The drug increases the efficacy of the corticosteroids per dose given, thus permitting the patient to be treated with lower doses of corticosteroids. The major side effects are leucopenia and thrombocytopenia. Nausea, vomiting, anorexia, and diarrhoea tend to only occur with high doses. Alopecia, rashes, fever, arthralgias, retinopathy, Raynaud's disease, pulmonary oedema, and pancreatitis have been described. 82021

The reported use of cyclosporin $A$ in AICAH unresponsive to corticosteroids and azathioprine is limited to two case reports. ${ }^{14} 15$ One was a 51 year old man who developed a hypersensitivity reaction to the azathioprine, the other was a 14 year old boy whose parents refused the use of azathioprine. Both cases were resistant to the use of high dose corticosteroids. Both had dramatic responses to the cyclosporin with minimal side effects.

Cyclosporin is a potent immunosuppressant drug. It acts by inhibiting the early events in $T$ helper cell activation that would normally lead to recruitment and expansion of the cytotoxic $T$ cells as well as to the activation of $B$ cell clones eventually secreting specific immunoglobulins. $^{22}$ Cyclosporin also interferes with the synthesis of interleukin 2 by activated $T$ cells. $^{23}$ The generation of other cytokines such as $B$ cell activating factor and interferon gamma are also inhibited. ${ }^{24}$ Cyclosporin does not, however, affect the development of suppressor $T$ cells, which decrease specific immune responses. The final result is a reduced expression of both the cell mediated and antibody mediated immune responses.

Cyclosporin does unfortunately have a number of side effects, the most important of which is nephrotoxicity, which may take a number of forms: a tubulopathy and peritubular congestion associated with acute toxicity, diffuse interstitial fibrosis, and arteriolopathy associated with longterm use. ${ }^{25-28} \mathrm{~A}$ recent study $^{29}$ found histopathological evidence of nephropathy in $21 \%$ of the renal biopsy specimens of patients receiving cyclosporin for autoimmune diseases. The commonest finding 
was that of stripes of interstitial fibrosis with tubular atrophy. A less common finding was that of arteriolar changes - a finding thought to be reversible on withdrawal of the drug. Other side effects associated with cyclosporin use include hypertension, hyperkalaemia, hyperuricaemia, anaemia, tremor, hypertrichosis, gingival hyperplasia, paraesthesiae, and gastrointestinal intolerance. ${ }^{30}$ Our patient has to date shown none of these side effects. In summary we present a case of AICAH refractory to high dose corticosteroids and azathioprine responding dramatically to cyclosporin. It seems to have a role in the treatment of corticosteroid resistant AICAH and thus merits further investigation.

1 Meyer zum Buschenfelde KH, Lohse AW, Manns M, Poralla T. Autoimmunity and liver disease. Hepatology 1990; 12: 354-63.

2 Cohen IR, Wekerle $H$. Autosensitisation of lymphocytes against thymus reticulum cells. Science 1972; 176: 1324-5.

3 Meyer zum Buschenfelde KH. Autoimmunity and live disease. Semin Liver Dis 1991; 11: iii-v.

4 Cook GC, Mulligan S, Sherlock S. Controlled prospective trial of corticosteroid therapy in active chronic hepatitis. $Q$ f Med 1971; 40: 159-82.

5 Page AR, Good RA, Pollara B. Long term results of therapy in patients with chronic liver disease associated with hypergammaglobulinemia. Am f Med 1969; 47: 765-74.

6 Murray-Lyon IM, Stern RB, Williams R. Controlled trial of prednisone and azathioprine in active chronic hepatitis. prednisone and azath
Lancet 1973; i: 735-7.

7 Davis GL, Czaja AJ. Immediate and long term effects of corticosteroid therapy for severe idiopathic chronic active hepatitis. In: Czaja AJ, Dickson ER, eds. Chronic active hepatitis: the Mayo clinic experience. New York: Marce Dekker, 1986: 26-42.

8 Summerskill WHJ, Korman MG, Ammon HV, Baggenstoss AH. Prednisone for chronic active liver disease: dose titration, standard dose, and combination with azathioprine compared. Gut 1975; 16: 876-80.

9 Wright EC, Seeff LB, Berk PD, Jones A, Plotz PH. Treatment of chronic active hepatitis: an analysis of three controlled trials. Gastroenterology 1977; 73: 1422-9.

10 Ellis CN, Fradin MS, Messana JM, Brown MD, Siegel MT, Hartley AH, et al. Cyclosporin for plague-type psoriasis Hartley $\mathrm{AH}$, et al. Cyclosporin for plague-type psoriasis -
result of a multi dose, double blind trial. $N$ Engl $\mathcal{F} M e d$ result of a multi dose,

11 Tugwell P, Bombardier C, Gent M, Bennet KJ, Bensen WG, Simon C, et al. Low dose cyclosporin versus placebo in patients with rheumatoid arthritis. Lancet 1990; i: 1051-5.
12 Bougners PF, Landais P, Boisson C, Carel JC, Frament N, Boitard C, et al. Limited duration of remission of insulin dependency in children in recent onset type 1 diabetes dependency in children in recent onset type 1 diabetes
treated with low dose cyclosporin. Diabetes 1990; 39: treated with

13 Masuda K, Nakajima A, Urayama A, Nakae K, Kogure M Inaba $G$. Double masked trial of cyclosporin versus colchicine and long term open study of cyclosporin in Behcet's disease. Lancet 1989; i: 1093-6.

14 Mistlis SP, Vickers CR, Darrock MH, McCarthy SW. Cyclosporin, a new treatment for autoimmune chronic active hepatitis. Med $\mathcal{Y}$ Aust 1985; 143: 463-5.

15 Hyams JS, Ballow M, Leichtauer AM. Cyclosporin treatment of autoimmune chronic active hepatitis. ment of autoimmune chro

16 Moddey WC. Chronic hepatitis. In: Zakim D, Boyer TD eds. Hepatology: a textbook of liver disease, 2nd ed. Philadelphia: WB Saunders, 1990: 1025-61.

17 Czaja AJ. Natural history, clinical features and treatment of autoimmune hepatitis. Semin Liver Dis 1986; 4: 1-12.

18 Schaffner F. Autoimmune chronic active hepatitis: thre decades of progress. Progress in Liver Disease 1986; viii: 485-503.

19 Wang KK, Czaja AJ. Pattern of side effects in corticosteroid treated $\mathrm{HBsAg}$ negative chronic active hepatitis: therapeutic implications. Gastroenterology 1987; 92: 1790-802.

20 Handschumacher RE. Drugs used for immunosuppression. In: Gilman AG, Rall TW, Nies AS, et al, eds. Goodman In: Gilman AG, Rall TW, Nies AS, et al, eds. Goodman and Gilman's The pharmacologic basi

21 Lawson PH, Lovatt GE, Gurton CS, Hennings RC. A review of the adverse effects of azathioprine. Adverse Drug React Ac Pois Rev 1984; 3: 161-71.

22 Shevach EM. The effects of cyclosporin on the immune system. Ann Rev Immunol 1985; 3: 397-423.

23 Bunjes D, Hardt C, Rollinghoff $M$, Wagner H. Cyclosporin A mediates immunosuppression of primary cytotoxic $T$ cell response by impairing the release of interleukin 1 and 2. Eur f Immunol 1981; 11: 657-61.

24 Reed JC, Prystowsky MB, Nowell PC. Regulation of gene expression in lectin stimulated or lymphokine stimulated expression in lectin stimulated or lymphokine stimus.

25 Mihatsch MJ, Thiel G, Spichtin HP, Oberholzer M Brunner FP, Harder F, et al. Morphological findings in kidney transplants after treatment with cyclosporin. Transplant Proc 1983; 15 (suppl 1): 2821-35.

26 Myers BD, Ross J, Neuton L, Leutscher J, Perloth $M$ Cyclosporin associated chronic nephropathy. $N$ Engl $f$ Med 1984; 311: 699-705.

27 Myers BD. What is cyclosporin nephrotoxicity? Trans Proc 1989; 21: 1430-2.

28 Lobo AJ, Juby LD, Foster PN, Rothwell J, Smith AH, Axon ATR. Oral cyclosporin and renal function in Crohn's disease. Gut 1989; 30: A1480-5.

29 Feutren G, Mihatsch MJ. Risk factors for cyclosporin induced nephropathy in patients with autoimmune disinduced nephropathy in patients with auto

30 von Graffenried B. Sandimmun (cyclosporin) in autoimmune diseases: overview on early clinical experience (status September 1987). Am $\mathcal{f}$ Nephrol 1989; 9: 51-6. 